\title{
Educational Policies in the United States and Implications for English Learners
}

\section{Políticas educacionais nos Estados Unidos e suas Implicações para aprendizes de inglês}

April Burke*

Purdue University

West Lafayette - Indiana / EUA

Luciana C. de Oliveira**

Purdue University

West Lafayette - Indiana / EUA

RESUMO: Este artigo oferece um contexto histórico para as políticas educacionais recentes nos Estados Unidos, especialmente aquelas relacionadas à lei "No Child Left Behind" (NCLB). O artigo explica os efeitos dessas políticas com relação a um segmento da população que vem crescendo muito, os aprendizes de inglês alunos que estão no processo de desenvolvimento de inglês como uma língua adicional. $\mathrm{O}$ texto explica muitas controvérsias e problemas relacionados ao uso de testes padronizados com essa população estudantil.

PALAVRAS-CHAVE: Politicas educacionais, políticas linguísticas, aprendizes de língua inglesa, Estados Unidos, Lei "No Child Left Behind", educação fundamental e ensino médio, história da educação.

ABSTRACT: This article provides a historical context for current educational policies in the United States, especially those mandated by the No Child Left Behind Act (NCLB). The article explains the effects of these policies on a rapidly growing segment of the U.S. population, namely English Learners (ELs), students who are in the process of developing English as an additional language. It explains several of the controversies and concerns related to the use of standardized tests with this student population.

KEYWORDS: Educational policies, language policies, English learners, United States, "No Child Left Behind" Act, K-12 education, history of education

Researchers from the United States of America have long shown the benefits of bilingual education for fostering not only second language (L2)

\footnotetext{
* amburke@purdue.edu. Ph.D. Candidate, Literacy \& Language Education, Dept. of Curriculum \& Instruction

** luciana@purdue.edu. Ph.D., ELL Licensure Program Director, Associate Professor, Literacy \& Language Education, Dept. of Curriculum \& Instruction
} 
attainment and academic achievement, but also a person's cognitive abilities and first language (L1) academic achievement (COLLIER, 1995; GREEN, 1998; THOMAS AND COLLIER, 1997). G. Richard Tucker (1999)states that since the 1970s, global evidence has been collected, which "demonstrates conclusively that cognitive, social, personal, and economic benefits accrue to the individual who has an opportunity to develop a high degree of bilingual proficiency when compared with a monolingual counterpart" (p. 338). Despite the evidence supporting bilingual education, when the Bilingual Education Act(BEA) expired in the U.S. in 2002, it was not renewed. Now, the education of minority language students is directed by the English Language Acquisition, Language Enhancement, and Academic Achievement Act or Title III of the No Child Left Behind Act (NCLB).

In 2001, NCLB passed with overwhelming support from both the Republican and Democratic partisan marked a new era in the history of U.S. public education, an era defined by the rapid progression of the high-stakes testing movement and an increased involvement of large corporations and foundations in the construction of the country's educational system. NCLB requires states to test all students in grades 3 through 8 (approximately ages 8-13) annually and once in high school, using standardized tests. Test scores are used to gauge student performance on content standards in Reading/ English Language Arts, Mathematics, Science, and Social Studies. Test scores are one of the primary ways of determining if a school has made adequate yearly progress (AYP). For example, a school can be deemed "failing" because one of its subgroups did not make AYP. Students are categorized into subgroups if they are identified as belonging to an ethnic minority, are English learners (ELs), have a disability, or if they receive free or reduced lunch. Schools which do not make AYP enter improvement status and are required to take a number of corrective actions. Lack of school funding to improve programming, use of test results to rank and compare schools, and the impact of annual testing on students and teachers has caused NCLB to become a very controversial law. According to Kate Menken (2008), "since the passage of the Bilingual Education Act in 1968, no federal education policy has as greatly impacted English language learners (ELLs) as No Child Left Behind (NCLB)" (p. 29).

This paper has two intentions: 1) to provide a historical context for current U.S. educational policies, especially those mandated by NCLB and 2) to explain the effects of these policies on a rapidly growing segment of the U.S. population, namely ELs. Consequently, the paper is divided into two sections. 
The first section provides an overview of the history of standardized test use in the U.S. prior to the passage of NCLB, a discussion of the increased role of the governmentinU.S. education, and a discussion of the influence of neoliberal economic theory on educational policy and schools in the U.S. The second section discusses the impact of U.S. educational policies on languageminority students and explains several of the controversies and concerns related to the use of standardized tests with ELs.

\section{A Historical and Ideological Context for Current U.S. Educational Policies}

\section{The Use of Standardized Tests in the United States Prior to World War II}

Editors Todd Price and Elizabeth Peterson (2009) preface their book The Myth and Reality of No Child Left Behind by describing the evolution of schooling in the United States as consisting of phases of serious contestation. In the first chapter of the book, Price (2009) asserts that a common thread through these different epochs, beginning in the Puritan colonies, has been the notion of democratic access to education. Even prior to the country's inception, there has been support for public schools, paid for through taxes with the intention of serving all members of a community.

In response to three waves of immigration which occurred during the 1840s, 1890s, and 1920s, the U.S. government began using statistics to document and categorize individuals. Price describes the use of statistics as a means of social control used to sort immigrants, determine their educational and work experiences, and predict how they would vote. The first documented use of standardized tests in the United States took place at the local level in Boston in 1845. It was not until the 1920s that standardized testing would become pervasive and viewed as a science (PRICE, p. 7-8)

In the late 1800s, classification systems were established and expanded upon in government, industry, and scientific institutions. The United States was rapidly becoming an industrialized nation and both the general population and the school-aged population were rapidly expanding. Setting standards and developing measurements was in vogue (KUSCH, 2009, p.16). The first test of intelligence was created in 1905 by the French psychologist Alfred Binet. In 1929, E.F. Lindquist, a psychology professor at the University of Iowa, created the Iowa Every-Pupil Testing Program which led to the development 
and administration of a statewide test called the Iowa test. The Iowa test was like an intelligence quotient (IQ) test, but its purpose was to identify students who needed extra help (LEMANN, p. 24-25).

Thus far, we have provided a historical overview of standardized test usage in the United States prior to World War II. With this historical precedent in mind, we now describe the political struggle regarding the federal role in education reform which ultimately led to the bipartisan passage of No Child Left Behind in 2001, the law which mandated the use of standardized tests for accountability purposes.

\section{Federal Role in Education Prior to No Child Left Behind}

This section relies primarily on Patrick McGuinn's (2006) analysis of the policymaking process in recent American education history. In his book No Child Left Behind and the Transformation of Federal Education Policy, 19652005, McGuinn provides a detailed account of the events and political maneuvers which eventually led to the passage of NCLB.

After World War II, education gained importance in the United States as graduating from high school became expected. In addition, the GI Bill which provided vocational or college education to veterans caused college enrollment to increase dramatically. Obtaining an education became established as a way to achieve social and economic mobility(MCGUINN, p. 27-28).

Prior to the 1954 Supreme Court Brown v. Board of Education decision, which said that segregation in public schools was unconstitutional, education policymaking in the United States had been primarily conducted at the local level. According to McGuinn, the Brown v. Board decision and the passage of The Elementary and Secondary Education Act (ESEA) of 1965 began a "new era" of federal involvement in educational policy. This era was marked by additional educational funding and safeguards which encourage equal access to education for disadvantaged students. At the heart of ESEA was Title I, which sought to improve the quality of education for low-income students by increasing per pupil expenditures(MCGUINN, p. 27).

Together, the ESEA and the National Defense Education Act(NDEA) caused federal funding of education to increase significantly from $\$ 375$ million to $\$ 4.2$ billion between 1958 and 1968. Also, the Civil Rights Act forbade federal funds from being allocated to segregated schools; therefore, the ESEA provided financial incentive for schools to desegregate. Despite these 
accomplishments, by the 1970 s and 80 s, the popularity of Title I and other social welfare programs established under President Lyndon Johnson's Great Society was diminishing. The public began to believe that these programs were creating a system of dependency (MCGUINN, p. 40).

Upon assuming the presidency, Ronald Reagan set out to undo much of what Johnson had established in regards to the role of the federal government in education. As McGuinn explains, "Reagan hoped either to eliminate the federal role in schools or to redefine the nature of the federal education policy regime by making privatization, choice, and competition p rather than equity - its guiding principles" (p. 42).

Although Reagan was not successful in his attempts to eliminate the Department of Education, he was able to reduce federal spending on public education by as much as 20 percent. Perhaps more importantly, Reagan was able to make a strong argument challenging the role of the federal government in public education. Reagan's legacy paved the way for New Democrats like future president Bill Clinton who found political opportunity in advocating for education and welfare reform (MCGUINN, p. 47).

\section{Political Struggle Leading to the Passage of NCLB}

Both the Democratic and Republican parties sought to use education reform to attract moderate and swing voters during the 1980s and 1990s (MCGUINN, p. 4). During the 1992 presidential campaigns, the education reforms proposed by Democrats and Republicans were very similar. Both parties called for the federal government to play a greater role in school reform and both focused on testing, standards, and school choice (MCGUINN, p. 83). Democrat Bill Clinton sought to use education reform to move his party in a more conservative direction. His call for testing, standards, and public school choice met great opposition from teachers' unions. The unions were successful in halting much of Clinton's education reform efforts during the 1990s. In 1994, Clinton signed the Goals 2000 Act into law. Goals 2000 marked a significant change in the role of the federal government from aiding the disadvantaged to holding schools accountable based on the performance of all of their students on standardized exams (MCGUINN, p. 83-92).

During the late 1990s, due to pressure from the business class, Republicans shifted their focus from the eradication of the Department of Education to testing and accountability. Republican George W. Bush made education reform the focus of his presidential campaign and his platform 
contained many of the reforms he had implanted in Texas such as testing, accountability, and school choice. Bush also called for an increased spending on education, which went against the established Republican position.During this time, liberal Democrats and leaders of the nation's prominent teachers' unions felt pressured to accept the education reforms being proposed, despite their opposition, as a means of preserving public education. There was a tremendous amount of pressure from business lobbyists to pass legislation containing provisions regarding accountability, testing, and standards. Some of the most active business groups in these efforts were Achieve Inc., the National Alliance of Business, and the Business Coalition for Excellence in Education (BCEE) (MCGUINN, p. 152-174).

Ultimately, the conference report on NCLB passed with overwhelming bipartisan support from both the Senate (87-10) and House (381-41). According to McGuinn, both parties made concessions; Democrats accepted testing and accountability measures and Republicans conceded vouchers and their proposals regarding Straight A's block grants which allowed states to receive federal money that could then be controlled at the local level.

The mandates and consequences of NCLB will be examined in the subsequent section. However, to better understand the ideology behind the passage of the law as well as the current high-stakes testing and standards movement, it is necessary to consider the prevalence of the economic philosophy known as Neoliberalism in the United States.

\section{The Influence of Neoliberalism on U.S. Schools}

Neoliberalism is an economic school of thought which has gained precedence in the U.S. within the last 25 years. Proponents of Neoliberalism argue for an unregulated market which frees capital from the constraints of government regulation and trade barriers. Neoliberals assert that profits can be maximized through the deregulation of industry and the privatization of public enterprises. In addition, neoliberals advocate cutting expenditures on health care, education, and other social services. Lastly, as Elizabeth Martinez and Arnoldo Garcia (1996) state, neoliberals focus on maximizing the benefits to individuals or individual corporations rather than supporting policies which would benefit the "community" or "the public good." This section examines how Neoliberalism, while not yet the dominant paradigm in U.S. education, has been gaining support and credence among education policymakers and stakeholders. The authors cited in this section provide a critical view of 
vouchers, school choice, and charter schools, as well as the influence of large, private foundations on U.S. education.

Diane Ravitch has been an educational historian since the mid-70s and served as assistant secretary of education under President George W. Bush. Formerly a leading proponent of NCLB and greater accountability through the use of high-stakes tests, she recently caused a stir by denouncing the act and its subsequent policies. Ravitch (2010) claims she initially supported school choice because she believed it would provide disadvantaged students the ability to transfer out of failing schools (a luxury which was already benefitting wealthier students); however, during her career she recognized that the unintended and negative consequences of NCLB far outweighed any benefits the act provided.

Ravitchexplains that both the Bush and Clinton administrations promoted neoliberal market reforms, including deregulation and privatization, to the public sector. Both the Democratic and Republican parties wanted to reform public education and argued that because the government had a monopoly on education, schools did not have any incentives to improve. Ravitch explains that although the corporate model was once considered a conservative agenda, now it has bipartisan support (p. 13). She explains, "I came to realize that the sanctions embedded in NCLB were, in fact, not only ineffective but certain to contribute to the privatization of large chunks of public education" (p. 102). Once a supporter of vouchers and charter schools, Ravitch now denounces the business model approach to education.

During the 1990s, there were three versions of school choice: voucher, privately managed, and charter. All three received public funds, but none were run by the government (RAVITCH, p. 121-122). Charter schools are often criticized for their ability to choose students. For example, numerous schools have been accused of selecting high performing minority students in order to achieve diversity while maintaining high test scores. This practice is referred to as skimming or cream-skimming. Schools find ways of limiting the number of low performing students in order to avoid sanctions resulting from AYP failure. Ravitch states that "[n] ow charters compete for the most successful students in the poorest communities, or they accept all applicants and push the low performers back into the public school system" (p. 146). This results in underrepresentation of certain populations such as English Learners and special education students. For example, in 2009 ELs constituted a fifth of Boston's public school enrollment, while only four percent of the students in 
charter schools were EL. In another example, which occurred in 2003, charters in Oakland were compared to public schools; they were found to have half the special education student enrollment.

Despite criticisms of charter schools and school choice, Ravitch explains that all of the presidents from Bush to Obama have lauded school choice. To support this claim Ravitch states that " $[\mathrm{t}]$ he Obama administration's Department of Education advised states that they would not be eligible for nearly $\$ 5$ billion in discretionary funds unless they eliminated any legal limits on the expansion of charter schools" (p. 145). Currently, there are approximately 1.4 million students enrolled in charter schools and 30,000 students enrolled in voucher programs nationwide.

Why do U.S. leaders support school choice when charter and private schools have not been demonstrated to provide superior educations? Part of the answer lies in the notion that the free market will remedy society's ills. Another contributing factor is the influence of big business on the government.Foundations allow very wealthy people to avoid paying taxes on part of their assets, and then apply the money they save toward socially beneficial endeavors. Philanthropists use their funds, often aggressively, to promote personal goals. The three largest education philanthropic foundations are the Bill \& Melinda Gates Foundation, the Broad Foundation, and the Walton Foundation.During the 2008 presidential campaign, the Gates and Broad Foundations invested heavily in Obama and secretary of education Arne Duncan. Jointly, they contributed $\$ 60$ million to make education reform a campaign issue and advocated for national standards, merit pay, and longer school days (p. 217). Ravitch asserts that large foundations are working aggressively to privatize public schools in the U.S. and their wealth and power allows them to avoid opposition which they might otherwise encounter through democratic processes (p. 200).

The information provided thus far is critical to understanding current U.S. educational policies. The implementation of President Franklin Roosevelt's New Deal programs in the 1930s and President Lyndon Johnson's Great Society programs in the 1960s marked a new era in the U.S., one marked by increased federal involvement in the regulation of industry and creation of public support programs such as Medicare and Medicaid which provide health insurance to people over age 65 and people with low incomes respectively. As a former teacher, Johnson was a strong proponent of federal aid to public schools. It was during Johnson's presidency that the Elementary 
and Secondary Education Act (ESEA) of 1965 and the Bilingual Education Act (BEA) of 1968 were passed. Starting in the 1970s, free market reformers and neo-conservative factions increased their efforts to undo these policies. President Reagan was intent on eliminating the Department of Education. While he was unable to do so, he was successful in challenging the effectiveness of the social welfare programs implemented under the New Deal and Great Society. Reagan paved the way for the centrist Democratic Leadership Council (DLC), which sought continued federal involvement but advocated accountability and standards (MCGUINN, p. 47). The result of the Democratic Party's shift to the right under President Clinton has been the development of a new era in educational policy. The centerpiece of compromise reached by Democrats and Republicans regarding education funding and the role of the federal government in educational policy making is the No Child Left Behind Act (NCLB). The following section describes the mandates set forth by NCLB and focuses on the effect of these mandates on disadvantaged and EL students.

\section{The Impact of U.S. Educational Policies on Language-Minority Students}

\section{No Child Left Behind Act Mandates Related to Disadvantaged and English Learner Students}

NCLB covers an array of topics in education. We limit our discussion to Title I-Improving the Academic Achievement of the Disadvantaged and Title III-Language Instruction for Limited English Proficient and Immigrant Students. In addition we describe many of the controversies and concerns related to the use of high-stakes tests with English learners (ELs).

\section{Title I-Improving the Academic Achievement of the Disadvantaged}

As stated in the law, the purpose of Title I is to "ensure that all children have a fair, equal, and significant opportunity to obtain a high-quality education and reach, at a minimum, proficiency on challenging State academic achievement standards and state academic assessments" (NCLB, Sec. 1001). Title I seeks to meet these goals primarily through assessments, curriculum aligned with state standards, teacher preparation, and targeting resources to educational agencies at the local level. The law also intends to reach these goals by closing the achievement gaps between disadvantaged children and their 
more affluent peers and between minority and nonminority students (Education Week, An ESEA Primer).

Part A of Title I is titled "Improving Basic Programs Operated by Local Educational Agencies". This portion of the law contains a number of NCLB mandates. Under Title I Part A, states are required to create standards for all primary and secondary school children and an accountability system (NCLB, Sec. 1111). The accountability system developed by each state is to include rewards and sanctions to ensure that local educational agencies will make adequate yearly progress (AYP). AYP is determined by individual states and based on student standardized test performance. States are to create annual measurable objectives (AMOs) and schools are to attain these objectives by improving student test performance. Tests must provide disaggregated data so that students in different groups can be compared, such as males to females or disabled students to nondisabled students.

In order for a school or school corporation to make AYP, a percentage of students in each subgroup must show improvement on standardized exams. If this percentage is not obtained, the school may use the safe harbor formula. The safe harbor formula allows schools to make AYP if the percentage of students in a subgroup who did not make AYP one year decreases by 10 percent the next year (<www.ncpie.org>).If a school corporation does not make AYP for two years, the school is place on Improvement status. If the school corporation continues to fail to make AYP, it faces a series of progressively harsher sanctions, including "restructuring". NCLB states that if a school that has been placed on corrective action continues to fail to make AYP after one school year, the local educational agency is to prepare to implement "alternative governance". Under NCLB, states are to take serious actions against failing schools such as:

(i) reopening the school as a public charter school;

(ii) replacing all or most of the school staff (which may include the principal) who are relevant to the failure to make adequate yearly progress; and

(iii) entering into a contract with an entity, such as a private management company, with a demonstrated record of effectiveness, to operate the public school (NCLB, Sec. 1111).

These options explain why schools place a great deal of importance on making AYP as well as on improving the test performance of students in subgroups. 


\section{Title III-Language Instruction for Limited English Proficient and Immigrant Students}

Many educators and researchers claim that a positive aspect of NCLB has been the attention it has afforded ELs. The intentions of NCLB are laudable as the following excerpts from Title III demonstrate.

The purposes of this part [Title III] are

(1) to help ensure that children who are limited English proficient, including immigrant children and youth, attain English proficiency, develop high levels of academic attainment in English, and meet the same challenging State academic content and student academic achievement standards as all children are expected to meet;

(2) to assist all limited English proficient children, including immigrant children and youth, to achieve at high levels in the core academic subjects so that those children can meet the same challenging State academic content and student academic achievement standards as all children are expected to meet, consistent with section 1111(b)(1);

The primary caveat to these noble intentions is the related system of accountability. Title III also states the following goal:

(8) to hold State educational agencies, local educational agencies, and schools accountable for increases in English proficiency and core academic content knowledge of limited English proficient children by requiring:

(A) demonstrated improvements in the English proficiency of limited English proficient children each fiscal year; and

(B) adequate yearly progress for limited English proficient children, including immigrant children and youth, as described in section 1111(b)(2)(B);

English learners are required to take the same exams as non-ELs. In addition, states are required to test the English proficiency of ELs in grades kindergarten through grade 12 in the following skill areas: listening, speaking, reading, and writing. States are allowed to grant ELs a one-time exemption from the reading/English language arts assessment if it is their first year of enrollment in a U.S. school. ELs are still required to be assessed in the other content areas.

A number of accommodations can be made for ELs on standardized exams. These include providing bilingual dictionaries and small group administration. If they are able to do so, states may also assess ELs for three to five years using exams in a student's first language. States are not required by law to include the performance of ELs who have been enrolled in U.S. 
schools for less than a year; however, all ELs still count towards the required 95 percent test participation rate. States may choose to include ELs who have exited the subgroup by attaining English proficiency when calculating AYP; however, they may only be included for two years after being reclassified as fully English proficient (FEP).

\section{Controversies and Concerns Related to the Use of Standardized Tests with English Learners}

The No Child Left Behind Act of 2001 and the high-stakes testing movement have become highly controversial due to the increased pressure they place on schools, administrators, teachers, and students. This section describes five topics related to the use of high-stakes tests with English language learners and the impact of NCLB on ELs and school corporations with large EL populations. The intention of this section is to illustrate the breadth and diversity of concerns related to high-stakes tests, especially in regards to their use with ELs. These topics are: (1) NCLB and the end of bilingual education policy, (2) the achievement gap between ELs and non-ELs, (3) issues related to the validity of high-stakes assessments when they are used with ELs, (4)the impact of high-stakes tests on ELs, and (5) EL issues related to Race to the Top and setting common standards.

\section{NCLB and the End of Bilingual Education Policy}

The American Bilingual Education Act (BEA) of 1967 was an amendment to the Elementary and Secondary Education Act of 1965. Before the BEA was passed into law in 1968, its wording was adjusted so that ELs were defined as "children of limited English speaking ability." In other words, rather than being viewed as potentially bi- or multilingual, ELs were defined as deficient (LEVINSON et al., 2007, p. 3; MENKEN, 2008, p. 30).

Progress was made in the 1970s. After the Lau $v$. Nichols decision, a systematic approach was implemented for identifying and providing services to ELs. However, in the 1980s under President Reagan, bilingual education came under attack. As Levinson et al. (2007) explain, "the Secretary of Education withdrew the 1980 regulations that defined compliance with bilingual educational policy. Further, federal funding for bilingual programs was cut by 47 percent between 1980 and 1988" (p. 3). At the same time that funding for bilingual education was dramatically cut, there was a tremendous increase in the number of ELs attending public schools. 
Three significant English Only initiatives are important to mention. In 1998, California voters approved Proposition 227, an English Only initiative targeted at the elimination of bilingual education, in a state with the largest numbers of ELs in the U.S. Arizona voters passed a similar measure in 2000, Proposition 203. Massachusetts voters followed and approved another state initiative, Question 2, and eliminated the oldest bilingual education law in the entire U.S. (MENKEN, 2008).

In 2002, the BEA expired and was not renewed under NCLB. While NCLB provides funding for the instruction of ELs, the programs are considerably different from those funded under the BEA. Current programs take an English-only and English immersion approach. As Menken (2008) explains, "The United States case is unique because it is a country that has a de facto language policy rather than an official language" (p. 34).

\section{The Persistent Achievement Gap Between ELs and Non-ELs}

The same groups who fared poorly on IQ exams of the early 1900 s continue to have lower test scores on today's mandated exams, namely the poor, English learners, learners with special needs, and members of minority groups. For example,A persistent achievement gap has existed between Hispanic and non-Hispanic white students. The U.S. The National Center for Education Statistics (NCES) issued a report on June 23, 2011, which explained that despite the fact that since 1990, Hispanic students have made significant progress on the National Assessment of Educational Progress (NAPE), white students have also made gains which have prevented the Hispanic population from catching up (SPARKS, 2011). The NAPE, which is referred to as the "Nation's Report Card," uses 0-300 and 0-to-500 point scales to measure the performance of representative samples of $4^{\text {th }}, 8^{\text {th }}$, and $12^{\text {th }}$ grade students nationwide in several subject areas including- science, mathematics, writing, civics, economics, and reading.A 10-point difference on the test equals approximately one grade level difference (Gorman \& National Center for Education Statistics, 2010; National Center for Education Statistics, 2011). As the following passage illustrates, the achievement gap between Hispanics and non-Hispanics is considerable.

As of 2009, Hispanic students trailed non-Hispanic white students by more than two grade levels across the board, including math gaps of 21 points in $4^{\text {th }}$ grade and 26 points in $8^{\text {th }}$ grade, as well as reading gaps of 25 points in $4^{\text {th }}$ grade and 24 in $8^{\text {th }}$ grade (SPARKS, 2011). 
Iris M. Chavez, a coordinator for the League of United Latin American Citizens (LULAC), explains that in Southwestern states with large Hispanic populations the achievement gap can be attributed to recent laws which require English-only instruction (SPARKS, 2011).

\section{Issues Related to Validity When Using High-Stakes Assessments with ELs}

Part A of Title I explicitly states that English learners are to be included in annual assessments and that the English proficiency of ELs is to be assessed annually. The law makes a provision for language assessments. It states that.

Each State plan shall identify the languages other than English that are present in the participating student population and indicate the languages for which yearly student academic assessments are not available and are needed. The State shall make every effort to develop such assessments and may request assistance from the Secretary if linguistically accessible academic assessment measures are needed. Upon request, the Secretary shall assist with the identification of appropriate academic assessment measures in the needed languages, but shall not mandate a specific academic assessment or mode of instruction. (NCLB, Sec. 1111)

The language in the above quote is indicative of the flexibility given to states as well the law's ambiguity. States are allowed to choose their own tests; however, to receive federal funding they must also guarantee that they are holding every individual school accountable.

There is a great deal of debate, both in theory and in practice, regarding the use of standardized assessments with ELs. Researchers and student advocates have raised a number of concerns related to these tests, including lack of research regarding accommodations for ELs, the validity of the tests when used with ELs, test maker bias, and the psychological impact of these exams on test takers.

Numerous researchers assert that the validity of standardized tests is compromised when they are used to assess ELs (AERA, 1999; ABEDI; HOFSTETTER; LORD, 2004; DURÁN, 2008; HERRERA; MURRY; CABRAL, 2007). According to the American Educational Research Association (AERA) (1999):

Test use with individuals who have not sufficiently acquired the language of the test may introduce construct irrelevant components to the testing process. In such instances, the test may not reflect accurately the qualities and competencies intended to be measured (p. 91). 
Nichols and Berliner (2008) note that many states are in violation of providing test accommodations to ELs as recommended by AERA to maintain test validity (p. 180-181). Stephen Sireci, Kyungtyek Han, and Craig Wells (2008) state that most standardized exams have only been tested for validity when used with ELs using three of the five measures recommended by the Standards for Educational and Psychological Testing (p. 128). In addition, Socorro Herrera, Kevin Murry, and Morales Cabral (2007) explain that it is important for educators to be aware of the variables of administration and situation which affect EL performance on standardized assessments. These variables include students' fluency in and comfort level with the language of the assessment (p. 165).

\section{Impact of High-Stakes Tests on ELs}

One positive aspect of NCLB is that it has caused people to pay attention to students who constitute subgroups (HUNT, 2009). Even researchers who are critical of and seek to improve current testing practices such as Jamal Abedi, Carolyn Hofstetter, and Carol Lord (2004) contend that inclusion of ELs in standardized national assessments is founded in judicial precedent and exclusion of ELs would cause "more harm than good" (p. 4-5).

Nichols and Berliner (2008) argue that high-stakes tests are extremely detrimental and have "created a climate that is often insensitive and marginalizing to students from different linguistic and cultural backgrounds" (p. 69). High-stakes tests put undue stress on students, lower their self-esteem, encourage them to drop out of school, and inhibit them from graduating from high school in addition to playing a major role in the increase of Englishonly programming (MENKEN, 2008, p. 30).

\section{Race to the Top, Common Standards, and ELs}

The American Recovery and Reinvestment Act of 2009 (ARRA) afforded $\$ 4.35$ billion for the competitive grant program called Race to the Top Fund. Funds were awarded to the states which were most successful at demonstrating that they were going to improve student outcomes, including achievement on standardized tests and graduation rates.

Three civil rights groups argued that the federal government did not give adequate attention to EL concerns when determining which states would receive funding. The executive director of Multicultural Education, Training, and Advocacy, Roger Rice said that the government didnot consider if states 
were narrowing the achievement gaps between ELs and their native English speaking peers. Rice also notes that the states with the largest EL populations were not awarded Race to the Top grants (ZHER, 2011d).

In January 2011, a draft notice regarding a \$10.3 million grant competition was published in the Federal Register. According to Education Week writer Mary Ann Zehr, the rules attached to the grant are likely to have major implications for EL policy decisions. The grant competition will lead to the development of new English proficiency tests under the Common Core State Standards Initiative. Currently, each state determines how to assess ELs and decides when students are ready to exit EL programming. The federal government is using the grant competition to encourage states to work together to develop English proficiency tests. Senior research associate for the education research firm WestEd, Robert Linquanti, praises the initiative, stating that "[i]t's going to start looking like a single national assessment for Englishlanguage proficiency, which it should. To the extent we have common standards and a common definition for [English-language learners], it's only going to help" (ZEHR, 2011a, 2011b).

\section{Conclusion}

The passage of the No Child Left Behind Act in 2001 marked a new era in U.S. education. Previously, the federal government provided funding to schools under Title I of the Elementary and Secondary Education Act. Under NCLB, the government continues to fund public schools, but schools must demonstrate that their students are achieving on standardized tests. The new accountability provisions of NCLB are controversial for a number of reasons. If a school is consistently unable to make adequate yearly progress, it could ultimately be closed down or taken over by a private company or the state. Making AYP is especially challenging for schools with large subgroup populations, including English learners and students of low socio-economic status.

NCLB has caused states and schools to pay greater attention to minority groups, including ELs; however, many leading researchers challenge current EL testing practices. The benefits and negative consequences of NCLB continue to be hotly debated as policymakers and stakeholders push for the reauthorization of the law, as well as a set of common standards and common assessments. Although English is not the official language of the U.S., NCLB covertly made English the de facto national language (MENKEN, 2008). We agree with Menken that NCLB "has become a means to suppress languages 
other than English in this country" (p. 35). Unfortunately for ELs, this is a difficult reality in a country comprised of immigrants.

\section{References}

ABEDI, J. et al. Assessment accommodations for English language learners: implications for policy-based empirical research. Review of Educational Research, Thousand Oaks, v. 74, n. 1, p. 1-28, 2004.

AMERICAN EDUCATIONAL RESEARCH ASSOCIATION, AMERICAN PSYCHOLOGICAL ASSOCIATION \& NATIONAL COUNCIL ON EDUCATIONAL MEASUREMENTS IN EDUCATION.Standards for educational and psychological testing. Washington, DC: American Educational Research Association, 1999.

BAKER, R. S. The paradoxes of desegregation: Race, class, and education, 1935-1975. American Journal of Education, Chicago, v. 109, n. 3, p. 320-343, 2001.

COLLIER, V. P. Acquiring a second language for school.National Clearinghouse for Bilingual Education, v. 1, n. 4, p. 1-11, 1995.

DURÁN, R. Assessing English-language learners' achievement. Review of Research in Education, Thousand Oaks, n. 32, p. 293-329, 2008. Disponível em: <http://rre.sagepub.com/cgi/content/full/32/1/292>. Acesso em: 1 maio 2011. EDUCATION WEEK. An ESEA primer. Bethesda, 2002. Disponível em: <http://www.edweek.org/ew/articles/2002/01/09/16eseabox.h21.html>. Acesso em: 1 maio 2011.

GREENE, J. P. A meta-analysis of the effectiveness of bilingual education.1998. Disponível em: <http://www.languagepolicy.net/archives/greene.htm>. Acesso em: 1 maio 2011.

HERRERA, S. G.; MURRY, K. G.; CABRAL, R. M. Assessment accommodations for classroom teachers of culturally and linguistically diverse students. Boston: Pearson Education, 2007. 336p.

HUNT, J. W. The modification of school improvement and staff development efforts in response to the failure to make adequate yearly progress. In: PRICE, T. A.; PETERSON, E. (Ed.). The myth and reality of no child left behind. Lanham: University Press of America, 2009. p.119-129.

INDIANA DEPARTMENT OF EDUCATION. Adequate Yearly Progress (AYP) Fact Sheet.Indianapolis, 2009. Disponível em: <http://www.doe.in.gov/ ayp/docs/2008/2008-AYPFactSheet.pdf>. Acesso em: 1 maio 2011. 
JOHNSON, A. W. Objectifying measures: The dominance of high-stakes testing and the politics of schooling. Philadelphia: Temple Press, 2009. 224p.

KUSCH, J. The chicken that wins: the history of assessment. In: PRICE, T. A.; PETERSON, E. (Ed.).The myth and reality of No Child Left Behind. Lanham: University Press of America, 2009. p. 13-26.

LEMS, K.; MILLER, L. D. English language learners in an era of NCLB. In: PRICE, T. A.; PETERSON, E. (Ed.).The myth and reality of No Child Left Behind. Lanham: University Press of America, 2009. p. 65-72.

LEMANN, N. The big test: The secret history of the American meritocracy. New York: Farrar, Straus and Giroux, 2000. 420p.

LEVINSON, B. A. U.; BUCHER, K.; HARVEY, L.; MARTÍNEZ, R.; PÉREZ, B.; RUSSELL, S. et al. Latino language minority students in Indiana: Trends, conditions, and challenges. Bloomington: Center for Evaluation \& Education Policy, 2007.

LINN, R. L. Scientific evidence and inference in educational policy and practice: Implications for evaluating adequate yearly progress. In: DWYER, C. A. (Ed.). Measurement and research in the accountability era. Mahwah: Lawrence Erlbaum Associates, 2005. p. 21-30.

MARTINEZ, E.; GARCIA, A. What is neoliberalism? A brief definition for activists. National network for immigrant and refugee rights.San Francisco, 1996. Disponível em: <http://www.corpwatch.org/article.php?id=376>. Acesso em: 1 maio 2011.

MCGUINN, P. No Child Left Behind and the transformation of federal education policy, 1965-2005. Lawrence:University Press of Kansas, 2006. 260p.

MENKEN, K. English learners left behind. Clevedon, United Kingdom: Multilingual Matters, 2008. 216p.

NICHOLS, S. L.; BERLINER, D. C. Collateral damage: how high-stakes testing corrupts America's schools. Cambridge: Harvard Education, 2008. 234p.

POPKEWITZ, T. Paradigm and ideology in educational research: The Social functions of the Intellectual. London; New York: Falmer Press, 1984. 208p.

PRICE, T. A. The book of testing. In: PRICE, T. A.; PETERSON, E. (Ed.). The myth and reality of No Child Left Behind. Lanham: University Press of America, 2009. p. 1-12.

PRICE, T.A.; PETERSON, E. (Ed.). The myth and reality of No Child Left Behind. Lanham: University Press of America, 2009. 161p.

RAVITCH, D. The death and life of the great American school system: how testing and choice are undermining education. New York: Basic Books, 2010. 296p. 
SIRECI, S. G., HAN, K. T., WELLS, C. S. Methods for evaluating the validity of test scores for English language learners. Educational Assessment, Mahwah, New Jersey, v. 13, n. 2, p. 108-131, 2008.

SPARKS, S. D. 20-year Hispanic academic achievement gap persists in math, reading. Education Week, 30 (36), 2011. Retrieved from: <http://www.edweek. org/ew/articles/2011/07/13/36hispanic-2.h30.html>.

THOMPSON, S. Public education and privatization in the ownership society. In: PRICE, T. A.; PETERSON, E. (Ed.). The myth and reality of No Child Left Behind. Lanham: University Press of America, 2009. p. 89-104.

THOMAS, W. P.; COLLIER, V. P. School effectiveness for language minority students. NCBE Resource Collection Series, Washington, D.C., National Clearinghouse for Bilingual Education, 1997.

TUCKER, G. R. A global perspective on bilingualism and bilingual education. In: ALATIS, J. E.; TAN, A. H. (Ed.). Language in our time: bilingual education and official English, ebonics and standard English, immigration and the Unz initiative Georgetown University Round Table on Languages and Linguistics. Washington, D.C.: Georgetown University Press, 1999. p. 330-340.

U.S. DEPARTMENT OF EDUCATION. The No Child Left Behind Act of 2001. Public Law. Washington, D.C., 2001. p. 107-110.

U.S. DEPARTMENT OF EDUCATION. Race to the top program executive summary. Washington, D.C., 2002. Disponível em: <http://www2.ed.gov/ programs/racetothetop/executive-summary.pdf>. Acesso em: 1 maio 2011.

ZEHR, M. A. Draft rules point way to consistency in ELL policies. Education Week.Bethesda, 2011a. Disponível em: <http://www.edweek.org/ew/articles/ 2011/04/06/27ells_ep.h30.html>. Acesso em: 1 maio 2011.

ZEHR, M. A. Ed. department backs English-proficiency tests for common standards. Education Week. Bethesda, 2011b. Disponível em: <http://www.edweek.org/ew/ articles/2011/01/10/17ellassess.h30.html>. Acesso em: 1 maio 2011.

ZEHR, M. A. ELL group urges enforcement of Mass. charter provisions. Education Week. Bethesda, 2011c. Disponível em: <http://blogs.edweek.org/ edweek/learning-the-language/2011/02/ell_group_urges_enforcement_of.html>. Acesso em: 1 maio 2011.

ZEHR, M. A. Group says ELLs got short shrift in race to the top. Education Week. Bethesda, 2011d. Disponível em: <http://www.edweek.org/ew/articles/2010/ 09/27/06ell.h30.html>. Acesso em: 1 maio 2011.

Recebido em 28/7/2011. Aprovado em 5/1/2012. 